\title{
Widowhood Rituals and Widow Inheritance in the Balikumbat, Cameroon
}

\author{
Nyongkah Rachel Tati* \\ Department of History and Archaeology, University of Bamenda, Cameroon
}

*Corresponding Author: Nyongkah Rachel Tati, Department of History and Archaeology, University of Bamenda, Cameroon

\begin{abstract}
In Balikumbat of Cameroon, just as in other parts of the world, widowhood rituals were an important aspect of indigenous culture which was commune. It was rather a means of giving the dead a befitting funeral which ushered them into the land of the spirit which was characterized by rituals and sacrifices to appease the gods and ancestors. In the traditional period, widowhood was not viewed as marginal or an ordeal melted upon widows. These rituals were officiated by elderly widows who identified themselves as the custodian of their culture. This paper seeks to examine widowhood among the Balikumbat Fondom of the Bamenda Grassfields of Cameroon. It highlights the reasons for its practice and the rationale and indigenous nature of widowhood and widow inheritance in the pre-colonial Balikumbat society. It also examines the norms associated to widowhood which were particularly applicable to Balikumbat widows. It further argues that, the institution of widowhood had experienced some evolutionary dynamics since the inception of modernity. Based on the data acquired mostly through orality, the paper concludes by stating that, widowhood was an inherent cultural practice of the Balikumbat people which has resisted cultural extinction and has moved into a revolutionary dimension to transcend the various historical periods.
\end{abstract}

Keywords: Rituals, Widowhood, Widows, Purification, Death.

\section{INTRODUCTION}

Death has always constituted an important aspect in the cultural life of people and rituals are observed for the sustainability of communities (Glaskin 2006: 107; Ejedepang-Koge 1986: 168). Widowhood rituals were characterized by exclusion, isolation and self-denial. Rituals in African communities were characterized by spiritual purification, prayers, incantation and sacrifices. The belief in widowhood rituals was absolute in the pre-colonial period while the colonial and post-colonial eras witnessed an evolution due to external influences. The elderly widows were the chief officiating actors during widowhood rituals. Elderly widows were once widows who had a mastery of the rituals and thus obtained the authority to partake in the rituals. In Balikumbat, the Voma cult was equally an active participant on the final day of the ritual. The members of the Voma cult had as a symbol of authority and power, the ancestral spear called the Ndingsooh necessary for the final rite.

As Martha Yiesi Ngum (2003: 1) and Samson Gunga (2009: 169) note, funerals were said to incorporate the deceased into the world of the dead and to separate them from the world of humans. Death has influenced cultures, behavior, beliefs and attitude of people since pre-historic times. Death and ghost were the main caprices of widowhood. In most parts of Africa, forced marriages, harassment, rejection and loneliness were associated to this transitional phase of a woman's life (Ibid). Contrary to popular thoughts in the contemporary period, Balikumbat women were never forced into widowhood rather, they embraced it as a way of life which was peculiar and inculcated in them. Thus, it was a part of their culture and heritage which should not be opposed or questioned. The societal and gender division of labour made it easier as each sex had its roles and obligations. Thus, each widow had as responsibility to subdue to ritual cleansing and pervert afflictions.

As pinpointed by Gunga (2009: 172), bride wealth was the basis of widowhood purification. Thus, the villages of the Bamenda Grassfields encouraged formal marriage procedure and the payment of bride wealth consolidated the marriage between two families. Through the payment of bride price, the woman's allegiance is transferred from her father to her husband. In customary marriage, bride price 
made a woman the property of the husband and had the prerogative to be inherited by her deceased husband's king rates. The institution of widowhood was well organized and inherent. It was under the authority of widowed paternal aunts and sisters of a husband. These women played an indispensable role to create a peaceful co-existence between the gods, spirits, ancestors and the man. The peaceful co-existence established peace, good health and prosperity in the family and the society at large. In this light, several reasons were accounted for the practice of widowhood in the Bamenda villages.

Widowhood rituals were ways to uphold justice and vengeance of the death of a spouse. The people had an overpowering belief in the ability of the ghost or death having an influence on the living. It was a communal belief that if a widow died during widowhood ritual, it was considered as prove of guilt for being responsible for the dead of the spouse (Sandyse 2001). The rituals were means to evoke the deceased to avenge his or her dead. Most often, the wife was usually held responsible for her husband's dead, even in the case of proven illness (Shiri 2007: 32; Ngalim 1992: 10; Sossou 2002: 8; Chima 1996: 3). It was a common perception that wives killed their husbands to inherit property or to free themselves from a marriage of misery. Widows were expected to undergo ritual purification and to respect all the norms associated to the ritual. This ritual was considered the only way to determine their innocence, and if guilty, the victim would face the wrath of the ancestors and the gods. Thus, the spirit of the deceased was to torment and haunt down the culprit (Chima 1996: 3, Akujob 2010: 7, Kamda 2005: 54). Most of the accusations were often unfounded as they mere strategy employed by greedy in-laws to appropriate the property left behind by the deceased.

Among the villages of the Bamenda Grassfields, dead was an important aspect which was treated with care and respect. Each community had its own sets of customs and ways of handling it. The widow was the closest person to the deceased husband and so it was normal for her to be cleansed from the calamity and spirit of death which made her to be unclean and impure (Sandys 2001: 9, Gunga 2009: 170, Sossou 2002: 8). This ritual was considered the perfect means to disconnect the spirit of the deceased spouse from the living spouse.

The widowhood ritual safeguarded and guaranteed the entrance and acceptance of the deceased spouse into the world of the ancestors. Ancestorhood was to be achieved only if all the norms associated to widowhood were rigidly respected (Ohale 2009: 3, Chima 1996: 9). It was presumed that, when the norms associated to widowhood were not properly performed, the deceased was denied access into ancestorship and the soul of the departed wandered and hovered about inflicting misery on the family and community at large. Thus, a satisfactory completion of this ritual necessitated a restoration of a peaceful co-existence between the living and the death (Gunga: 2009: 169).

Widowhood ritual served as a mark of transition or change of social status from a married woman to that of a widowed woman. Psychologically, widowhood purification was seen as a sort of therapy which is preventive, protective and curative. It was believed that when the rituals were not performed, the victim might be inflicted by madness, swollen legs and stomach. In this effect, family members took the obligation that, their relations were properly cleansed to advert such situations.

The elderly widows at times implemented the ritual with impunity, after all, they had equally gone through such ordeals. When a married man died, his female widowed relations assembled in his to commence with the ritual purification (Chima 1996: 4, Gunga 2009: 171, Sossou 2002: 8).

\section{RATionale ANd Indigenous NATURe OF Widowhood in PRe-Colonial Balikumbat}

Just as in many parts of the world and Africa in particular, as cited by Mamphela in her "Political Widowhood in South Africa: the Embodiment of Ambiguity (2009)" that, the rituals was characterized by heat, darkness and dirt as they depended on local custom. As we shall discover in the course of this paper, Balikumbat widows performed widowhood rituals for a duration of one week. When a woman lost her husband, she automatically became a widow (vahkinn). She was placed under the authority of elderly widows who were in charge of the purification. Before the burial of her husband, she sat on the bare floor closed to the corpse with and open palm stretched on her laps (interview with Doh Salleh, Luma Banabas, Labiah Esther). During burial, the widow was asked to swear her innocence on the corpse, this was a means of evoking the spirit of the deceased to fight for vengeance. Immediately after burial, the widow was taken to the stream, bathed and dressed in quashi, a traditional attire made of plantain leaves just to cover the front genital part. A corner was prepared for her in a smoky kitchen in which she had to sleep on plantain leaves same as the elderly 
widows. The elderly widows were women who had once gone through the said rituals and have a good knowledge of the various rites, items and beliefs associated with widowhood.

The widow was given a pair of split calabash in which she was to eat and drink from and was not to wash hands before or after meals. She was equally restricted, secluded and excluded. A widow was not to indulge in certain conversation, not to laugh and to cry at the top of her voice for a period of eight days. The widow sat on the floor with legs stretched out with her two big toes close to each other and hands open on the lapse to symbolize the openness and purity of her heart. Her movement was very limited and was accompanied by the elderly women everywhere she went. Based on the judgment made by the elderly widows, her hut was constantly heated up to protect her from the harsh cold of the night.

On the third day, as recounted by Malah Agnes a onetime widow, she was taken to a stream where her head, eye brawls, armpits and private parts, that is, the genital, were shaved. She was bathed and rubbed with palm oil. The quashi she wore was buried by the stream and she was dressed in another quashi. Back home, a bed of eleven bamboos was made on which she slept on for three months. The widow was bathed once every eight days in a particular stream by the elderly widows. After three months, the elderly widows, family members and friends assembled in the compound of the deceased. She further elaborated that, on a fixed day, she and the elderly widows got up as early as 5am to dispose the bamboo bed on which she had slept on in a bush. She was also taken to the stream for a second ritual bath, her hair was shaved again. A stream in Balikumbat was considered a dwelling place for some deities and the flowing nature of a stream washed and cleansed the widow from dirtiness and the pollution of death. While at the stream, incantations, prayers and offerings were made. She was rubbed with a mixture of palm oil and some herbal concoctions and dressed in a black sackcloth which she wore for a period of nine months. After nine months, came the last ritual which marked the end of the widowhood. At this point, the widow was pronounced free and could remarried or could be inherited by her in laws. It was forbidden for a widow to become pregnant during the period of the ritual and as such considered a taboo worth another purification rite (Interview with Samjeh Ignatius).

The other items used during the rituals were buried by the stream. At that juncture, the services of a clan cleanser were sought to conclude this phase of the rituals. Under the authority of the clan cleanser, the widow was taken to a junction where some rites were performed. The widow was then dressed in a black sack cloth to mourn her husband for a period of one year. She was freed from the severe widowhood norms and could live a normal life. After a period of one year, she was given the last bath and a celebration for haven completed the rituals (interview with Doh Alfred and Samjeh Ignatius).

Widow inheritance or levirate marriage was another aspect of widowhood which was a common practice in many parts of African and Bamenda villages in particular. Among the people of Kenya as Nancy Luke (2001) records, widow inheritance was a normal occurrence in which a widow was inherited by one of her husband's brothers or other close male relations. She further stipulates that inherited widows were better off than non inherited widows. In Balikumbat, after the death of a husband, his widow was expected to be inherited by the deceased relations. The traditional people believed that widow inheritance provided the widow with considerable security (Dah 1995: 25, Sandys 2001: 8). The word levirate comes from a Hebrews word levir which means brother-in-law. This was an ancient custom which was practiced among the Semitic people and the Arabs of Yemen (Holy Bible, Ruth Chapter 1:9-21, 4:1-6, Deuteronomy Chapter 25:5-10). In most villages, widows were to remarry their brothers in law or the successor of their husband as this gave the widow a considerable security (Sossou 2002: 8). Widowhood inheritance was based on two considerations, the age of the widow in question and her child bearing ability. The levirate husband had as responsibility to act as a father figure to her children and in pertaining rituals and to beget children in the name of the deceased brother and to preserve the continuity of the lineage (Luke, 2001: 5, Gunga 2009: 171). He managed the property held in trust for the widows young children. The levir had to provide the widow and her children with shelter and food. The levir equally had as duty to provide labour on the widow's farm.

Widowhood inheritance preserved and maintained a continuous relationship between the widow, her children and the deceased family. Through widow inheritance, the levir became the widow's sore 
legitimate sex partner and the children produced from such relationship continued to bear the name of the deceased husband. The widow was prohibited from having additional sexual partners (Luke: 2001:5). It should be noted that, the new partnership between the widow and the levir was not equated to marriage but both parties had fewer rights and obligation when compared with a normal marriage. As such, inherited widows experienced a high degree of autonomy as most of them continued to reside in their deceased husband's house rather than relocating to the levir's compound. In some situations, a dying husband chose a levir for his wife. Most often, he chose one of the younger brothers or nephews based on their personal relations and trust.

Most levir accepted to inherit widow(s), because it provided them with wealth. The traditional economy was characterized by subsistence agriculture, so men needed the widow and her children to provide labour for their farms. Equally, they received bride wealth from the widows grown up daughters which increases their wealth. Through the levirate marriage, the levir had a direct influence over the property of the deceased brother, thereby exploiting them for his own interest. Through widowhood inheritance, men gained higher social status and political influence based on the number of children and wives they had. So, it gave men the opportunity to obtain a privileged social position.

In the traditional period, the levirate marriage was viewed positively rather than detest since it was a mechanism employed by culture and the society to provide and carter for widows and their children (Sandyse, 2001: 3-7). The political, economic and social position of women in this period contributed positively to this practice. Women were under oppression and so were not involved in the making of decisions that concerned them, thus the custom was dictated upon them. In Balikumbat, widows who opposed to be inherited were obliged to refund the bride price that was paid if not, the widow was practically forced into the levirate marriage. But as modernity came with new dispensations, the levirate marriage was bound to experience tremendous opposition. Although the levir had as duty to carter for the widow and her family, the levir had a primary obligation to his own wives and children. Thus, his support to the widow was limited as she became an extra burden to the levir. Levirate marriage was later considered, baseless, old fashion and out dated. Widows turned to rely more on their personal effort and those of their children and people of good will (Luke 2001: 6, interview with Lebiah, Bobga, Buma).

The economic upliftment of some widows empowered them financially and so had no reasons to seek the support of a levir. The empowerment of widows liberated them from oppression, discrimination and abuses. The tendency of abuse was very high as most levirs became more interested in the grabbing of property than in assisting the widows and their children. Also, with the growth in western education, Christianity and the wide spread of HIV AIDS, men lost interest in inheriting widows and polygamy equally witnessed a sharp decline (James P.M. et al: 1999).

\section{EVOLUTIONARY DYNAMICS OF WIDOWHOOD SINCE THE INCEPTION OF COLONIALISM}

With the coming of foreign forces, the widowhood rituals were bound to undergo some changes and modifications. Sama Margaret explains that the implantation of Christianity in Balikumbat in 1922 later followed by western education brought in changes which were not only felt in the political and economic aspects, but equally in the social and religious spheres. The new dispensations or forces came with new ways of life as oppose to the traditional period. The missionaries and administrators were perplexed as regards widowhood rituals. They criticized and condemned the practice which they classified as gross superstition, barbaric, paganic and satanic. Sama Margaret further explains that with the creation of Christian churches and formal schools, the instructors and preachers sorted ways to convert indigenes mentally to accept some changes in their life. In same light, Samjeh Ignatius notes that, the missionaries saw widowhood rituals as a kind of slavery especially to the widows because of its demoralizing and dehumanizing nature and thus concluded that widows and women were treated as second class citizens. This thought is buttressed by Ngalim (1992:37) who elaborates that, the missionaries took it as a responsibility to change or if possible abolished certain aspects of indigenous culture which were tantamount to human underdevelopment.

In this effect, the Catholic Church divided its members into small Christian groups under indigenous leaders who were overseers of the activities of the members under their leadership and those who went contrarily to the teachings of the church were reported to the missionaries. Those who violated the principles of the church were suspended from playing led role in certain activities of the Church especially in the Holy Sacrament. In the same vein, men who inherited widows were also restrain 
from church activities. These created an atmosphere of embracement, shame and disgrace. Due to the privileges accorded converts in the Church, they were determined to uphold the new order. This created a socio-cultural gulf between the converts and the non converts (Ngalim 1992: 39).

The missionaries used the Bible as a weapon to fight against widowhood rituals as they quoted several Biblical passages to counteract widowhood rituals. According to the Bible, God recommended remarriage for widows who could not withstand temptation but not forceful remarriage. They instructed the converts on how to mourn as prescribed by the Holy Bible by quoting " you are the people of the Lord your God, so when you mourn for the dead, do not gash yourself or shave the front of your head as pagans do (Holy Bible, Deuteronomy 14:1, Exodus 22:22-24).

According to Sama Margaret and Samjeh Ignatius, the Church was very critical with its members during these circumstances. Wives of Church workers and converts were not to be subjected to widowhood rituals. When a female member of the Church lost her husband, members of her group assembled in her home to share her grief. Christian widows were to sit on a chair and receive condolences from friends and relatives. She was not to refrain from talking or handshakes, not to be dressed half naked, she was instead dressed in white accompanied by her church members who sang and danced to the Lord. This relieved the widow from widowhood rituals. The church encouraged widows to put their trust in God and to be of exemplary behavior (Dah 1995: 20).

The rate of scolarization greatly increased among the indigenes of the North West Region during colonialism and post colonialism. Kemende Margaret and Manyi Kobe go on to observe that people became literate and adopted foreign culture. They transmitted these foreign ideas to their off-springs. Most of the educated people frowned at some aspect of their society such as ancestor worship, funeral rites and widowhood rituals. Equally, scholarized workers had limited time to undergo the rituals. In order for this to be achieved, the number of days for the ritual was reduced to one week or even less. The belief in widowhood rituals experienced a great modification as the educated folk and Christians gradually changed their perception towards traditional religion and widowhood rituals in particular. Most widows refused to subject themselves to what they termed inhuman treatment. Some out rightly refused to go around half naked. They refused to respect some of the norms dictated to them by the elderly widows. Because of this, modern widows were permitted to bath at dawn in order not to be seen by the public. Thus, they could wash their face, hands and mouth. The elderly widows with no educational background were obliged to fit themselves into their program. Among the Ibo, Chima (1996) records, prolonged cultural practices and rituals were considered as an impediment to economic growth, liberty and a violation of human right. These views made the rituals less relevant as more people embraced foreign cultures. Most indigenes turned to the church for their spiritual needs and cleansing which according to them, it provided them with the necessary protection. The issue of the sackcloth was another area where change was observed. In the post-colonial era, widows found it difficult to wear just one or two dresses for a period of one year during mourning. This was more complicated when the widow concerned was a nurse or working class women, thus the norms of widowhood rituals became more of a symbolic ritual than a practical ritual.

Urbanization has equally had an effect on widowhood rituals in the Bamenda Grasfields of Cameroon. In same thought as Gyimah (1975:452), Africans had been made to understand that certain traditional practices were harmful to the individual and the community. Most city dwellers adopted urban cultural life in the city in which traditional practices were seemingly absence. They were more concerned with the hustling and bustling in cities. This was because certain rituals slowed down economic activities and so saw prolonged rituals as an obstacle to their progress. As a result, they were determined to emancipate themselves from such rituals. After a few days of the symbolic rituals, they returned to the city and continued with their normal activities in which they disassociated themselves from most of the roles and restrictions associated to widowhood rituals.

As observed by the Chair persons of the Balikumbat traditional council, Sama Augustine and Ladji Stephen, the Fon of Balikumbat was the custodian of their culture and tradition, thus had overpowering influence over their subjects. With the advent of modernization, the Fon became aware of the ills attached to widowhood rituals. The crowning of Gahgwanyin III in 1977, brought in a remarkable change in the institution of widowhood. He was conscious of the fact that exposing the nakedness of widows was undignifying, humiliating, pitiful, primitive, archaic and widely criticized. Thus, he made some prohibitions to reduce the plight of widows during widowhood rituals. In this 
light, the number of days for the ritual was reduced drastically. He further pronounced that widows were to tie a white piece of cloth from the chest level down to the legs. Another change was brought in by his predecessor Fon Gahnyamnyin III. Gahnyamnyin took over from his father in 2012 and in April 2017, he declared that widows could either put on a white gown or a loin cloth and a white blouse during widowhood purification. These measures were greatly welcomed by the Balikumbat people. These measures have been a formidable reason for the survival of the rituals.

Also, the government of Cameroon had enacted many laws which protected women from certain obnoxious cultural practice such as widowhood rituals and inheritance. These laws went a long way to protect and safeguard the rights of women. Educated women who could read and interpret the laws defend themselves against violation. In the Civil Status Registration Ordinance No.81/02 of June, 1981 (Extract of the O.G. of the U.R.C. No 14 of August 1981, some laws were enacted to protect widows. These included section 77 (1) which stipulated that the death of a man dissolves the marriage, ends the relationship and any obligations that arose under it. Section 77 (2) reiterated that in the event of death of the husband, his hier shall have no right over the widow, nor over her freedom or the share of property belonging to her, it may provide that she observes the period of widowhood of one hundred and eight (180) days, from the date of the death of her husband, freely remarry without any one laying claim to whatever compensation at the marital benefit for dowry or otherwise, received either at the time of engagement, during marriage or after marriage. Also, where the levirate is practiced against the widows will, it amounts to the offence of forced marriage under section 356 (1) of the Penal code and it attracts a punishment of up to ten (10) years imprisonment and a fine of up to one million francs (1000000) CFA.

On the $9^{\text {th }}$ of May, 2003, the government of Cameroon signed and rectified the convention on the elimination of all forms of discrimination against women, it seeks to promote and protect women's right (CEDAW). This law protected widows as they were considered as human beings possessing all attributes. The government carried out many awareness seminars, conferences to educate women on their basic rights. It equally put in place specific structures for widows to consult when their fundamental rights were trample upon. These apparatus included the legal department, the ministries of Social Affairs and Women Empowerment and the Family.

In 2008, the North West Women Empowerment Forum (NOWWEF) was created which had as objective to empower women especially widows of the North West Region and to promote growth and alleviate poverty. This forum promoted the education of the girl child, adult literacy programs with proactive leadership skills and promoted strategic actions towards political participation and in decision making. They had organized many seminars and workshops which educated and enlightened women on their rights. They equally organized media activities that promoted and enhanced women's rights. Thus, women became aware of their rights and so rejected the cultural practice of widow inheritance.

Besides, another association known as the International Federation of Female Lawyers (FIDA, 2006) carried out a wide campaign against widowhood rituals. It educated women more especially widows on their rights and to abstain from cultural practices known to infringe on their rights. These practices included: widowhood rituals, wife battering, early and force marriages, rape, female genital mutilation, legitimation of children and inheritance rights. Their motive to fight for the abolition of malicious and repugnant cultural practices that subject, debase and humiliate women. It also instilled the desire for women to accept change and adjust to modernization which was the only way to free themselves from the whims and caprices of widowhood rituals which were repugnant to natural justice, good conscience and equity. In this regard, this association assisted widows who brought their cases to them. This group was composed of female lawyers and activists who assisted widows with the necessary information and a follow up of their cases.

The media equally offered sensitization programs to the public some of which were presented in pidgin English for the information to be understood by the grassroot population especially women. In 1996, the Cameroon Radio Television (CRTV) created a television program called Women and Development. In the same light, there was another radio talk called Women's Corner. These created awareness within the public in general, and women in particular. In this light, some educated and courageous widows out rightly rejected widowhood rituals and the levirate marriage as out-law and an impediment to their empowerment. They made threats on their in-laws, this scared them as they 
became conscious of the aftermath. With the aforementioned laws in place, few widows decided to mourn their deceased husband based either on the prescription of the Church or the legal framework. However, despite the above forces of change, widowhood rituals have stood the test of time as it has remain one of the age old cultural aspects which has transcended the various historical times.

\section{The PersistenCe OF Widowhood Rituals}

Throughout history, African women have been the upholders of their culture and have protected it against extinction. Although Christianity and the government have put in place certain frameworks to protect widows and their rights, widowhood rituals has continue to play vital role in communities across the country and Africa in general. The subject of death and life is very pertinent in cultures and as such should be handled with absolute care. Most indigenes of Balikumbat in the North West Region of Cameroon continued to respect their customs and tradition as they saw them as the only authentic means to give a deceased spouse a befitting burial which facilitated his/her entrance into ancestor hood. They considered their culture as a treasured inheritance from their forth fathers (Lang 2015:60). The severity of the implications for those who failed to perform widowhood rituals frightened many widows who dreaded being mad, developing swollen legs and stomach. Based on what upholds in Balikumbat, just one widow has totally rejected performing the rituals while most widows rather embarked on symbolic cleansing (interview with Malah, Dohwankis, Tuma, Nyahlum and Ladji). Thus, it was not just the widows who dreaded the implications of not performing the rituals, the members of the widow's family took upon themselves the obligation to supervise the ritual processes. This was to make sure that their daughter or sister was effectively purified to advert the wrath of the gods and ancestors. For this reason, the ritual has been passed on from one generation to another.

Some elderly widows enjoyed the notorious distinction of being identified as the few villagers who have categorically rejected the abandonment or modification of widowhood rituals. They took upon themselves the responsibility to purify widows in and out of their family. This was because their services were sorted in families which do not have elderly widows or the adequate knowledge needed for the rituals. The rituals were mastered through experience, observation and frequent participation in what was termed native law and customs. In order to adjust to the changing realities of time, the elderly widows have decided to perform the rituals on victims depending on the time allocated by the victims in question. This has greatly led to a reduction of the number of days for the rituals that is from three months to one month, to one week and later to few days. This has caused the rituals to become more symbolic as the required blueprint is often overlooked. The elderly widows refrained from the half-naked dressing of the widow to the wearing of contemporary mourning dress. In the Bamenda Grassfields, especially in Balinyonga, they have resorted in tying a white loincloth above the breast to the legs. With these adjustments done, widows have no reason to oppose this cultural aspect since it was the last honour and respect paid to their deceased husband.

Women constituted a greater proportion of the rural and illiterate population. This was attributed to African culture in which girls were trained informally to become housewives. At the early periods of the introduction of modern education, families gave their sons more opportunities than girls. Some of the girls who went to schools ended as dropouts because of unwanted pregnancy, forced or deliberate marriages and poverty. Consequently, most of them were ignorant of their rights and so became victims of repugnant cultural practices. On the other hand, most educated women attributed the persistence of widowhood rituals to the slow nature of the legal system of Cameroon. The legal procedures were almost inactive thereby discouraging widows from fighting for their fundamental rights. In some cases, those who violated these rights were never punished due to the corrupt nature of most court officials. The filing of a case against a transgressor entails time and money which was not affordable by most widows in distress moments. Well to do in-laws could influence the case in their favour thereby increasing the plight of the widows. Furthermore, most women contracted customary marriage which was not acceptable by the legal system. Thus, customary marriages were redressed based on the laws and custom of the people. In this case, widows were treated according to their cultural prescription. For this reason, most rural widows saw nothing wrong with the rituals since other widows had gone through it.

In accordance with the thoughts of Wilscon and Strattan, most African communities were patriarchal and so produced patriarchal frameworks in which gender division was the order of the day. Patriarchy 
refers to the power relations in which women's interest were subordinated to those of men. These power relation cuts across organization and rituals. Women were considered as only daughters, wives and widows of men. In such societies, men dominated over women and the elderly over the younger. Women and widows were expected to respond to lifelong subjugation which went a long way to promote cultural practices. Women under patriarchal influence lacked the capacity and mandate to oppose their culture. Widowhood rituals were implemented as the only legitimate method to vindicate a widow from the accusation of killing the husband (Wilscons 1996: 4, Stratton 1994: 133-142).

Although most of the villages in the Bamenda Grassfields were Christianized, the Christian religion has not been able to do away with the indigenous belief system associated with traditional religion. The church seems to have failed to provide the widows with the required protection against the spirit of death which was purportedly achieved only through widowhood rituals. Most widows were in a crossroad or dilemma, as they continued to observe ancestral rituals which caused them to boycott church services.

\section{CONCLUSION}

This paper has examined widowhood rituals in the Balikumbat community in Cameroon's northwest. It has highlighted the reasons for the rituals which were anchored on their belief system. This paper asserts that widowhood rituals in the traditional period were communal and absolute. From the analysis of data, widowhood rituals in Balikumbat just as in many parts of African have mutated under the weight of Christianity and western civilization. Ensuing from this is the fading of the ritual's communal and absolute status, despite its continuing importance and persistence in the society. Aspects of the ritual such as outfit, duration, and nature of the rituals have undergone significant modifications. In the year 2006, this cultural practice experienced a serious setback as a widow out rightly rejected to undertake the rituals, arguing that they conflicted with her Christian principles. It was equally observed that some indigenes who were converted into Christianity, though devoted to this new religion did not find spiritual protection, thus, they continued to observe widowhood rituals. This dilemma notwithstanding, the study found that, widowhood has resisted persistent campaigns for its eradication. The study thus concludes that widowhood persists as an important aspect of indigenous cultural life given most of the indigenes still see the practice as the only proper and acceptable way to mourn a deceased spouse.

\section{REFERENCES}

[1] Akujob, R., "Yesterday You Were Divorced, Today I Am a Widow: An Appraisal of Widowhood Practices and the Effects on the Psyche of Widows in Africa", Department of English and Literary Studies, College of Human Development, Covenant University, Ogun State, Nigeria, 2010.

[2] Anonymous, Gender and Development Fund of the Canadian Cooperation Support Office Yaounde, FIDA Publication, 2006.

[3] Chima, J.K., "Widowhood Among the Igbo of Eastern Nigeria", Master Dissertation, Philosophy in History, University of Bergen, Norway, 1996.

[4] Ejedepang-koge, S.N., The Tradition of a People Bakossi: A Historic-Socio-Anthropological Study of One of Cameroon Bantu People, SOPECAM, Yaounde, 1986.

[5] Glaskin, K., "Death and the Person: Reflection on Mortuary Rituals" in Transformation and Ontology in an Aboriginal Society, Vol.52, 2006.

[6] Gunga,O.S., "The Politics of widowhood and Remarriage Among the Luo of Kenya", in A Journal of the Philosophical Association of Kenya, New Series, Vol.1, Department of Educational Foundation, University of Nairobi, Kenya, 2009, 165-178.

[7] Gyimah, F.O, "The Traditional African Women Face a Face with the Modern World", in The Civilization of the Woman in African Tradition, Abidjan, Presence Africain, Paris, 1975, 451-464.

[8] James, P.M, "The Effect of the AIDS Epidemic on Widowhood in Northern Uganda", in Department of Population Studies, Makerere University, Kampala, Uganda, 1999, 211-224.

[9] Kamda, A.R, "Le Veuvage Chez Les Ngyemba de l'Ouest Cameroun, de la Period Pre-coloniale a 1960: Essai d'Analyse Historique", Maitrise Dessertation, Department of History, University of Yaounde 1, 2005.

[10] Lang, M.K., "The fight Against Infertility Through Indigenous Religious Rituals in the Bamenda Grassfields, The Case Study of the Kenbeum in Weh Fondom Since Pre-colonial Times", in Indigenous Political Hierarchy and Sustainable Collective Meaning in the Changing Cameroon Grassfields, Edited by Mark Bolak Funteh, United Kingdom, Dignity Publishers, 2015, pp. 43-65. 
[11] Luke, N., The Cultural Significance of Widowhood: Widow Inheritance and the Position of Luo Widows in the 1989 Kenya Census, Jessup Street, Philadelphia, U.S.A, 2001.

[12] Ndah, N.G., Chieftaincy, Widowhood and Ngambi in Cameroon, Pforzherm, Hohenwart, 1995.

[13] Ngalim, G.T., "Widowhood in Nso Traditional Society: Theological Reflection”, Bambui Seminary, Bambui, 1992.

[14] Ohale, "The Perpetuation of Injustice Against Women: Reflection on Widowhood Practices in Africa and the Task of Challenging the Status Quo", Department of English, Foreign Languages and Literatures, Chicago, State University, 2009.

[15] Sandyse, E., "Widowhood: Invisible Woman Secluded or Excluded", in United Nations Division for the Advancement of Women's Right, 2001.

[16] Sossou, M., "Widowhood Practices in West Africa: The Silent Victims", in International Journal of Social Welfare, Online Publication, 2002.

[17] Stratton, F., Contemporary African Literature Politics of Gender State, Routledge, London, 1994.

[18] WILSCONS, H., Women and Literature in Britain 1500-1700, Cup, Cambridge, 1996.

[19] Yiesi, M.N., "Death and Funeral Celebration in Oku, Contemporary Widowhood Practices", in Journal of Applied Social Sciences, Vol.3, No 1, 2003, 108-129.

[20] Regional Archive Bamenda, File No, N.W/Saled.2007/21/Bk. SHIRI, M.H.A., Menopause and Widowhood, 2007.

[21] Regional Archive Buea, File N.W. Saled, 2008/54/Book.

\section{AUTHOR's BIOGRAPHY}

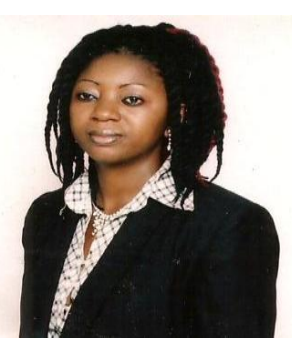

Dr. Nyongkak Rachel Tati was born in the North West Region of Cameroon. She obtained her B.A, M.A and PhD in the University of Yaounde I in 2017. Tati is currently teaching in the History and Archaeology Department , University of Bamenda. She is a researcher and has published few scientific articles on the same Subject.

Citation: Nyongkah Rachel Tati. "Widowhood Rituals and Widow Inheritance in the Balikumbat, Cameroon”. International Journal of History and Cultural Studies (IJHCS). vol 4, no. 1, 2018, pp. 56-64. doi:DOI: http://dx.doi.org/10.20431/2454-7654.0401004.

Copyright: (C) 2018 Authors. This is an open-access article distributed under the terms of the Creative Commons Attribution License, which permits unrestricted use, distribution, and reproduction in any medium, provided the original author and source are credited. 